\title{
Naturally Occurring Asbestos in Argentina: A Compilation of Case Studies
}

\author{
Lescano Leticia, Locati Francisco, Marfil Silvina, Sfragulla Jorge, \\ Bonalumi Aldo, and Maiza Pedro
}

\begin{abstract}
In Argentina, asbestos is associated with meta-mafic or meta-ultramafic igneous rocks, mainly serpentinites (or steatized varieties) and amphibolites, and less commonly with dolomitic rocks (in metamorphic and metasomatic domains). Chrysotile, anthophyllite and tremoliteactinolite were identified as the main asbestiform minerals (in the range of respirable particles). Chrysotile occurs mainly in serpentinites or steatized rocks as well as in amphibolites and other host rocks nearby. It appears filling veins, as slip and cross-fiber, generally associated with fissures or shear zones. Amphibole asbestos, mainly from the tremolite-actinolite series and anthophyllite, commonly occurs together with a non-asbestiform counterpart within the same area and deposits. These minerals have been found in talc ores as well as in vermiculite-rich sectors, or filling fissures in meta-mafic and meta-ultramafic rocks. In this compilation, the results of case studies on mines from the provinces of Córdoba, Mendoza and San Juan (Argentina) are summarized, and
\end{abstract}

L. Leticia $(\square) \cdot$ M. Silvina $\cdot$ M. Pedro

UNS-CGAMA (CIC de la Prov. de Bs. As-UNS), San Juan 670, 8000 Bahía Blanca, Argentina

e-mail: leticia.lescano@uns.edu.ar

M. Silvina

e-mail: smarfil@uns.edu.ar

M. Pedro

e-mail: pmaiza@uns.edu.ar

L. Francisco

CICTERRA (CONICET-UNC), Av. Vélez Sarsfield 1611,

X5016GCA Córdoba, Argentina

e-mail: locatifrancisco@gmail.com

S. Jorge $\cdot$ B. Aldo

Secretaría de Minería (Provincia de Córdoba)-FCEFyN (UNC),

Av. Vélez Sarsfield 1611, X5016GCA Córdoba, Argentina

e-mail: sfragulla@gmail.com

B. Aldo

e-mail: bonalumi.aldo@gmail.com new data from the western sector of the Pie de Palo Complex are included.

\section{Keywords}

Asbestiform minerals - Geological occurrence •

Argentina

\section{Introduction}

In a general sense and from a commercial perspective, the term "asbestos" is defined as a group of six minerals (chrysotile, crocidolite, amosite, tremolite, actinolite and anthophyllite) that occur in nature forming bundles of thin and long fibers. They are characterized by having high tensile strength and flexibility, low thermal and electrical conductivity, high absorbance and thermal stability, and resistance to chemicals (Ross et al. 2008). This definition not only has a mineralogical-morphological basis but also alludes to the physicochemical characteristics of the fibers. According to the World Health Organization (WHO 1986) and different regulatory agencies worldwide, respirable asbestos fibers with diameter $<3 \mu \mathrm{m}$ (and additionally a length $>5 \mu \mathrm{m}$ and a length to diameter ratio $\geq 3: 1$ ) should be considered hazardous, because they represent the most biologically relevant part of the alveolar fraction. In this compilation, the term "asbestos" is used as a synonym of "asbestiform fibers" for those minerals that can be separated longitudinally into thin and long fibers (excluding cleavage fragments, Gunter 2010) and meet the aforementioned size criteria.

Asbestos generally occurs associated with magnesiumrich (often also iron-rich) rocks affected by metamorphic and/or metasomatic processes. Forming environments typically display shear or evidence for a significant influx of silica-rich hydrothermal fluids (Van Gosen 2007). The rocks that can host asbestos include altered or metamorphosed varieties of ultramafic and mafic rocks (mainly in ophiolitic 
complexes), dolomitic rocks, iron formations, and alkalic intrusions and carbonatites (e.g., Van Gosen 2007; Vignaroli et al. 2014).

In Argentina most asbestiform minerals are associated with metamorphosed and/or metasomatized mafic and ultramafic igneous rocks, mainly serpentinites and amphibolic rocks, talc and vermiculite deposits as well as with dolomitic rocks (Angelelli et al. 1980; Locati et al. 2014; Lescano et al. 2016a). Their production started in 1920, stimulated by the industrial use of asbestos in postwar years, but they have been banned since 2003 (Rodríguez 2004). However, asbestos research is still important in Argentina because many active mines and future projects can potentially incorporate asbestiform fibers during the exploitation works (e.g., serpentinite, talc, vermiculite and carbonate deposits).

This paper summarizes the results of case studies on mines from the provinces of Córdoba, Mendoza and San Juan (Argentina) where asbestiform minerals were identified. Detailed geologic and mineralogical descriptions of Argentine asbestos are not presented in this article, but the papers that are referenced herein provide the complete information. Furthermore, we present new data of samples from the western sector of the Pie de Palo Complex (San Juan province). Mineral abbreviations after Whitney and Evans (2010) were adopted.

\section{Geological Occurrence of Asbestos}

\subsection{Asbestos in Meta-Mafic/Ultramafic Rocks}

In Argentina mafic and ultramafic igneous rocks are widely distributed in the provinces of Córdoba, Mendoza and San Juan, among others, and have been affected by different metamorphic and/or metasomatic processes (Ramos et al. 2000). These rocks have been mined for decades to extract amphibolite and serpentinite, but also to produce talc, vermiculite and asbestos in minor proportion.

Chrysotile occurs in meta-ultramafic rocks (mainly in serpentinites or steatized rocks) as veins with irregular banding, growing transversely to the fissures (cross-fiber asbestos) and could be interpreted as the product of fluids circulating along fissures (or shear zones) during late metamorphic episodes (Bonalumi and Gigena 1987). In some sectors these veins are also identified in meta-mafic rocks (amphibolites) or in the host rocks (mainly amphibolic/ chloritic schists or gneisses). In the province of Córdoba, chrysotile is present in diverse serpentinic bodies such as those of the mines "Los Guanacos", “25 de Mayo", “Árbol Seco", "La Bélgica", "Los Congos", among others (Fig. 1a). The "La Bélgica" mine, one of the most important chrysotile deposits in Argentina (Fig. 1b), was active for about
30 years (Lescano et al. 2015). In the province of San Juan chrysotile veins affecting serpentinite rocks were also documented (e.g., the "Don Leon" mine, Castro de Machuca 1981), while in the province of Mendoza these types of veins with asbestiform chrysotile were identified in serpentinites near the "La Judita" mine (Lescano et al. 2017a).

Amphibole asbestos occurs in meta-ultramafic and meta-mafic rocks, filling veins, and associated with vermiculite and talc-rich zones. In the province of Córdoba veins with fibrous anthophyllite were identified in serpentinites as well as in amphibolites in the "Adita" mine (Lescano et al. 2014) and the "Coco Solo" mine (Angelelli et al. 1980) respectively.

Several vermiculite mines in the province of Córdoba ("Los Guanacos", "Penachos Blancos", "La Saltona", "La Soledad", "Inés II" and "Rosarito", among others) were studied to determine the presence of asbestiform minerals. Vermiculite mineralization developed in biotite-rich zones in the contact between igneous bodies (mainly pegmatites) and meta-ultramafic rocks or in fractures, and it is interpreted as the product of reaction between igneous fluids and minerals of the meta-ultramafic rock. Amphibole groups are present in all the vermiculite deposits studied, but only in "Los Guanacos" and "Rosarito" mines (Fig. 1c) asbestiform tremolite was identified (Lescano et al. 2013a, 2017b).

Prismatic and fibrous amphiboles are commonly observed associated with steatized ultramafic bodies or in the contact zone with the host rock in different mines of Argentina. However, only in the "Salamanca" mine in the province of Mendoza scarce asbestiform amphiboles (tremolite-actinolite series) were detected in the contact zone between the steatized body and the host rock (schist) (Lescano et al. 2013b).

\subsection{Asbestos in Dolomitic Rocks}

Pure and impure dolomitic rocks are recognized in different provinces of Argentina, generally not associated with asbestos. In the province of Córdoba they correspond to metamorphic rocks (marbles) that appear as lens or tabular banks with different metamorphic grades associated mainly with gneisses, migmatites, amphibolites, and ultramafic rocks (Sfragulla et al. 1999). In general, minerals of the amphibole group are prismatic or acicular, tremolite being one of the most common accessory minerals in the impure varieties. In the Altautina area, marbles are dolomitic to calc-dolomitic, and they are limited by quartz-biotite gneisses or schists. In the contact zone a metasomatic belt can be recognized, where gneisses/schists are enriched in biotite. In this sector, asbestiform tremolite in veins crosscutting marble foliation or in discontinuity planes was identified (Locati et al. 2014). In the province of San Juan, the Pie de Palo Complex is composed of gneisses, schists 

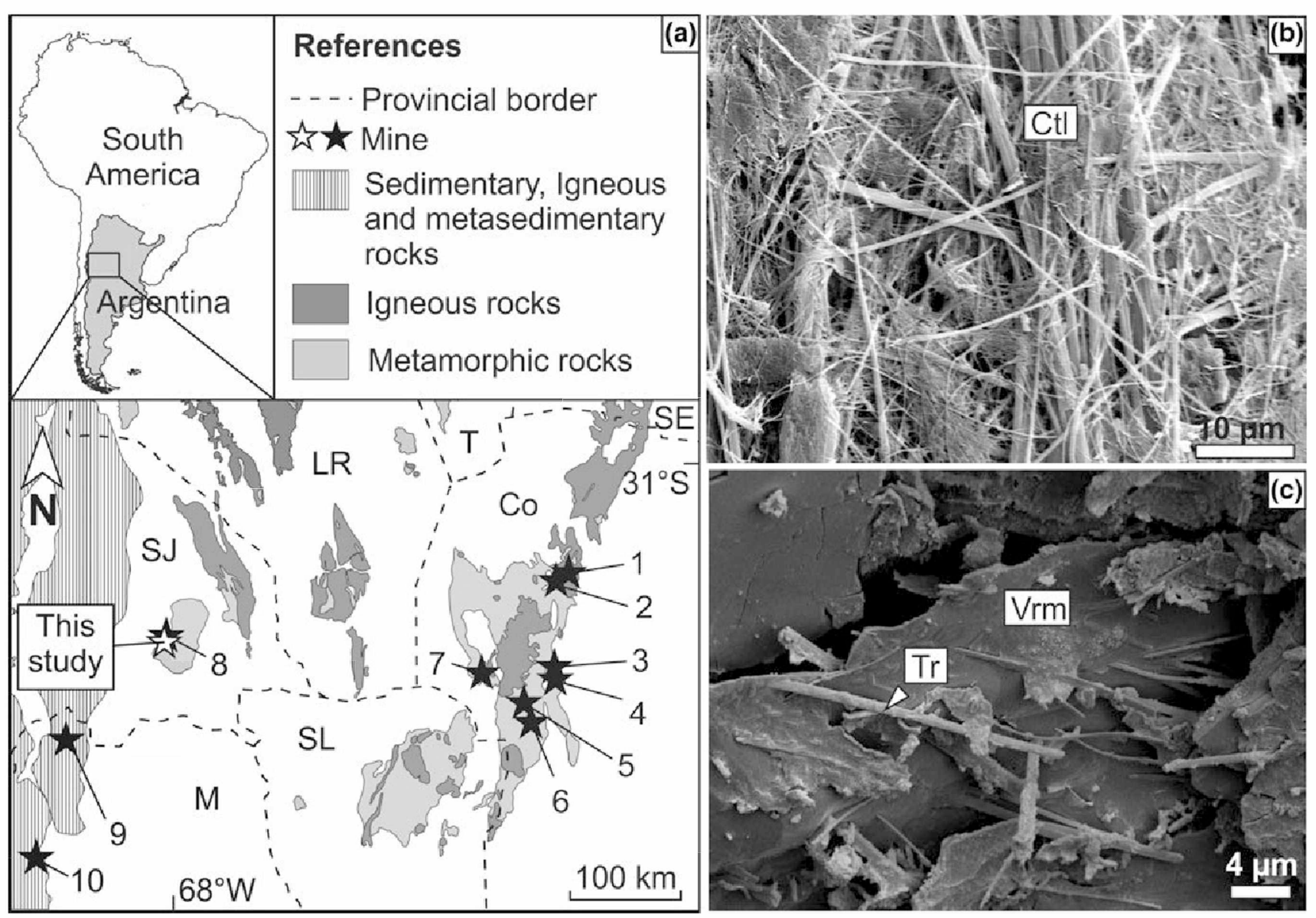

Fig. 1 a Schematic map of the main geological units of the central-western part of Argentina and the mines cited in the text. $M$, SJ, Co, T, SL, SE and LR: Mendoza, San Juan, Córdoba, Tucumán, San Luis, Santiago del Estero and La Rioja provinces respectively. Numbers 1-10: Mines (1-"La Saltona", 2-"Rosarito", 3-"Adita", 4-"La Soledad", 5-"La Bélgica" and "Los Congos", 6-"Penachos Blancos",

and metamorphosed mafic and ultramafic rocks (serpentinites, meta-gabbros, meta-diorites, amphibolites and mafic schists). In this area hydrothermal fluids produced important talc deposits such as those in the "Don León" mine (Castro de Machuca 1981). In these alteration zones asbestiform actinolite was identified as impurities in dolomite in the Quebrada del Gato sector (Lescano et al. 2016b).

\section{Asbestiform Minerals from Quebrada La Petaca (San Juan)}

In this work two samples (A and B) from Quebrada $\mathrm{La}$ Petaca in the western sector of the Pie de Palo Complex (province of San Juan), $1 \mathrm{~km} \mathrm{SW}$ of the "Don León" mine, were studied (Fig. 1a). Its geological setting is similar to that of Quebrada del Gato (Naipauer et al. 2010).
"Los Guanacos", "Inés II", "Árbol Seco", "Coco Solo" and "25 de mayo", 7-Altautina area, 8-"Don Lébn", 9-"La Judita", 10-"Salamanca". White star: new samples from Quebrada La Petaca. b Secondary electron image (SEM) of chrysotile from "La Bélgica" mine (Lescano et al. 2015). c Secondary electron image (SEM) of tremolite in vermiculite from "Rosarito" mine (Lescano et al. 2017)

The mineralogical characterization of samples was performed by polarizing microscopy (Leica DM EP) on thin sections and X-ray diffraction (XRD) on powder samples with a Rigaku D-Max III-C diffractometer $(35 \mathrm{kV}, 15 \mathrm{~mA}$, $\mathrm{Cu} \mathrm{K} \alpha$ radiation). The diffraction patterns were recorded between $3^{\circ}$ and $60^{\circ} 2 \theta$ in steps of $0.04^{\circ} 2 \theta$ and $1 \mathrm{~s}$ counting time per step. Morphological studies were conducted by scanning electron microscopy (SEM) with a Carl Zeiss EVO ma100 microscope at $20 \mathrm{kV}$, equipped with an energy dispersive X-ray spectrometer (EDS), on gold-coated samples.

Sample A corresponds to a foliated serpentinite composed of antigorite, magnetite and prismatic tremolite ( \pm chlorite and dolomite) (Fig. 2a, b). In this sample, calcite, quartz and chrysotile veins $(\sim 250 \mu \mathrm{m})$ crosscutting serpentinite foliation were recognized (Fig. 2c).

Sample B corresponds to a talc-chlorite schist composed of talc, chlorite and dolomite ( \pm antigorite, magnetite and 


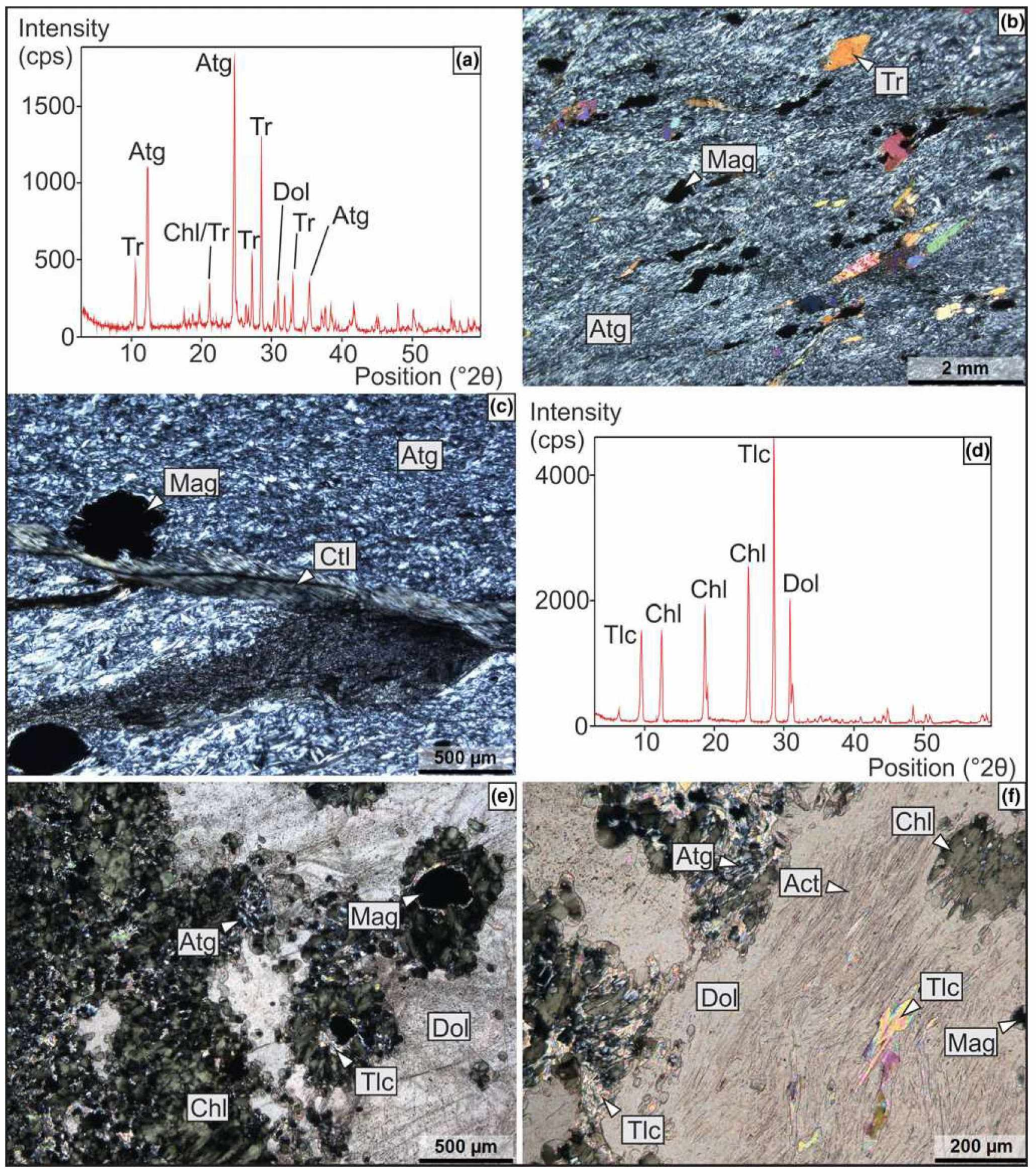

Fig. 2 a XRD pattern of foliated serpentinite (sample A). Main reflections are marked. b, c Photomicrographs of sample A (crossed nicols). b General texture of the rock. c Detail of a chrysotile vein. d XRD pattern of talc-chlorite schist (sample B). Main reflections are

marked e, $\mathbf{f}$ Photomictographs of sample B (crossed nicols). e General texture of the rock. $f$ Detail of actinolite fibers and talc sheets included in dolomite 

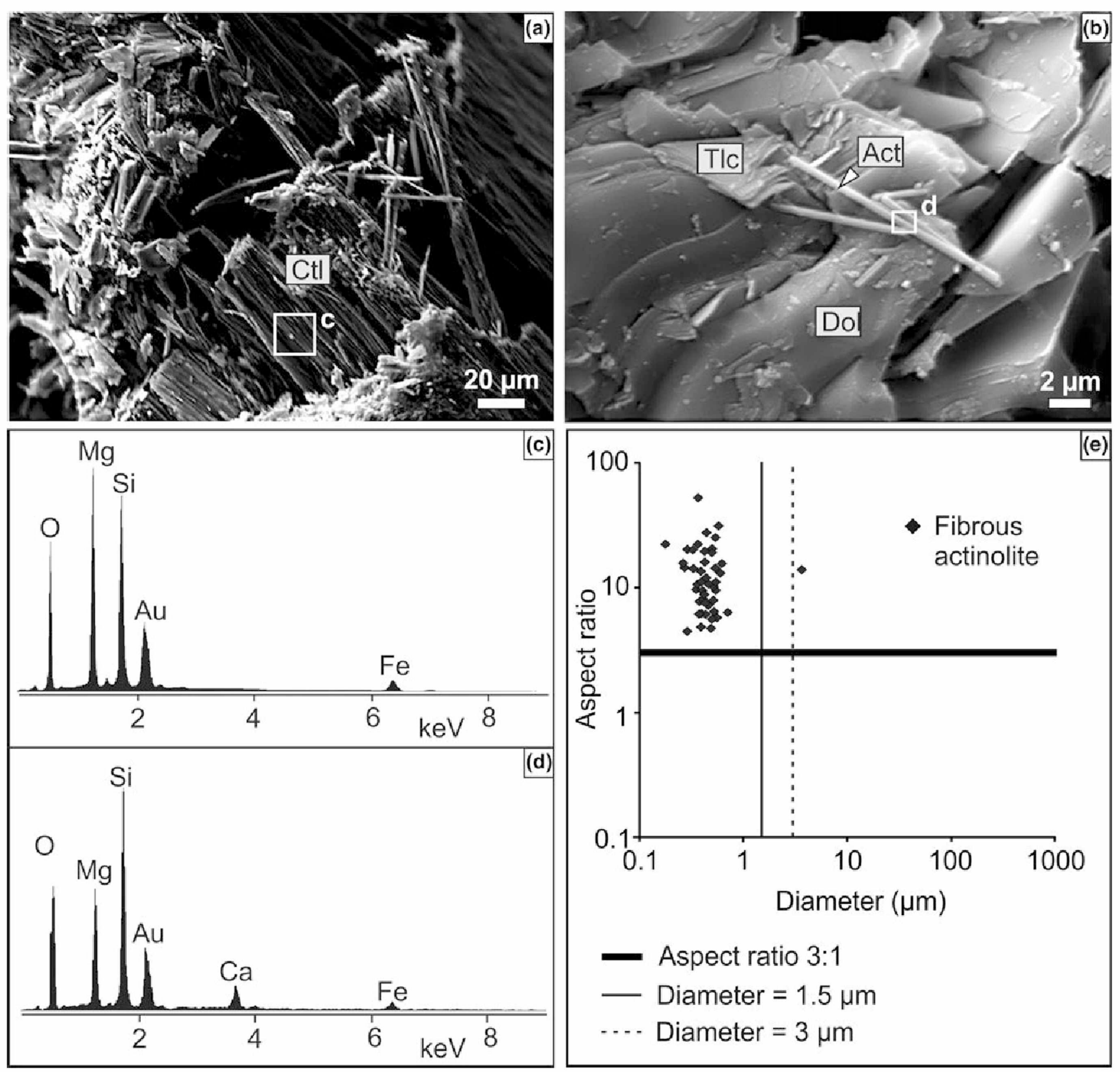

Fig. 3 a Secondary electron image (SEM) of chrysotile fibers from a vein in sample A. Sector "c" corresponds to the area analyzed by EDS. b Secondary electron image (SEM) of actinolite fibers associated with talc sheets in dolomite from sample B. Sector "d" corresponds to the

area analyzed by EDS. $c$ EDS spectrum of chrysotile in sector "c". The iron peak is assigned to intermixed iron oxides. d EDS spectrum of actinolite in sector "d". e Comparative graph (diameter vs. aspect ratio) of actinolite crystals from sample $B$

clay minerals) (Fig. 2d, e). Oriented inclusions of talc and very thin fibrous actinolite were observed in dolomite crystals (Fig. 2f).

Fibrous phases in both samples (chrysotile vein and actinolite in dolomite) were studied by SEM-EDS on broken surfaces. Chrysotile appears as bundles of thin, long fibers (Fig. 3a), $>5 \mu \mathrm{m}$ in length and $<3 \mu \mathrm{m}$ in diameter, generally associated with iron oxides (Fig. 3c). In general, the main diameters vary between 0.8 and $1.6 \mu \mathrm{m}$; however, the exact

length of the fibers could not be determined. Actinolite appears as thin prismatic fibers associated with folded sheets of talc in the dolomite (Fig. 3b, d). Fifty actinolite crystals were measured in order to analyze their morphology (Fig. 3e). All fibers have an aspect ratio (length to diameter ratio) $>3: 1$, and most fibers are $<1.5 \mu \mathrm{m}$ in diameter (except for one crystal). The length of the fibers varies between 1.3 and $52 \mu \mathrm{m}(\sim 42 \%>5 \mu \mathrm{m})$. According to these results and the morphological limits set by the WHO (1986), 
meta-mafic/ultramafic rocks from Quebrada La Petaca in the western sector of the Pie de Palo Complex may contain asbestiform fibers (chrysotile and actinolite) in the range of respirable fibers.

\section{Conclusions}

- In Argentina, asbestos is associated with meta-mafic/ultramafic rocks, mainly serpentinites (or steatized varieties) and amphibolites, and less commonly with dolomitic rocks (in metamorphic and metasomatic domains).

- Chrysotile, anthophyllite and tremolite-actinolite were identified as the main asbestiform minerals.

- Amphiboles in talc and vermiculite deposits are present in most of the samples, but their morphology is not always asbestiform.

- In the western sector of the Pie de Palo Complex, meta-mafic/ultramafic rocks with asbestiform chrysotile (in veins) and asbestiform actinolite (as inclusions in dolomite) were recognized.

Acknowledgements Financial support was provided by PICT $2011 \mathrm{~N}^{\circ}$ 153 (FONCyT), PUE 2016-CONICET-CICTERRA and SECyT-UNC 05/I708. Authors thank CICTERRA (CONICET-UNC), CIC (province of Buenos Aires) and the Geology Department of the UNS.

\section{References}

Angelelli, V., Schalamuk, I., Fernández, R.: Los yacimientos de minerales no metalíferos y rocas de aplicación de la región Centro-Cuyo, vol. XIX, p. 261. Secretaría de Estado de Minería. Anales, Buenos Aires, Argentina (1980)

Bonalumi, A., Gigena, A.: Relación entre las metamorfitas de alto grado $\mathrm{y}$ las rocas básicas y ultrabásicas en el Departamento Calamuchita, Córdoba. Rev. Asoc. Geol. Argentina 42(1-2), 73-81 (1987)

Castro de Machuca, B.: Génesis de la mina de talco "Don León", sierra de Pie de Palo, provincia de San Juan VIII. Congr. Geol. Argentino, San Luis IV, 535-555 (1981)

Gunter, M.E.: Defining asbestos: differences between the built and natural environments. Chimia 64(10), 747-752 (2010)

Lescano, L., Marfil, S., Maiza, P., Sfragulla, J., Bonalumi, A.: Amphibole in vermiculite mined in Argentina. Morphology, quantitative and chemical studies on the different phases of production and their environmental impact. Environ. Earth Sci. 70 (4), 1809-1821 (2013a)

Lescano, L., Marfil, S., Maiza, P.: Análisis morfológico de anfíboles en menas de talco de la provincia de Mendoza. Rev. Asoc. Geol. Argentina 70(3), 401-409 (2013b)
Lescano, L., Bonalumi, A., Maiza, P., Sfragulla, J., Marfil, S.: Asbestiform amphiboles in a serpentinite quarry in operation, province of Córdoba, Argentina, vol. 5. In: IAEG XII Congress, Torino, Italy, pp. 615-618 (2014)

Lescano, L., Marfil, S., Maiza, P., Sfragulla, J., Bonalumi, A.: Crisotilo en serpentinitas de mina La Bélgica, provincia de Córdoba. Rev. Asoc. Geol. Argentina 72(4), 542-550 (2015)

Lescano, L., Marfil, S., Sfragulla, J., Bonalumi, A., Locati, F., Maiza, P.: Asbestos in Argentina: mineralogical and morphological characterization. Environmental impact. In: Simmons, D.L. (ed.) Asbestos: Risk Assessment, Health Implications and Impacts on the Environment, vol. 8, pp. 145-190. Nova Science Publishers, Hauppauge (2016a)

Lescano, L., Locati, F., Sfragulla, J., Marfil, S., Bonalumi, A., Maiza, P.: Actinolita de morfología asbestiforme en carbonatos de la Quebrada del Gato, provincia de San Juan. Acta Geol. Lilloana 28 (1), 174-176 (2016b)

Lescano, L., Locati, F., Marfil, S., Sfragulla, J., Bonalumi, A., Maiza, P.: Presencia de minerales asbestiformes en la mina de talco La Judita, Yalguaraz, provincia de Mendoza. In: XX Congr. Geol. Argentino, Tucumán, pp. 53-55 (2017a)

Lescano, L., Locati, F., Sfragulla, J., Marfil, S., Bonalumi, A., Maiza, P.: Asbestiform and non-asbestiform morphologies in a talc and vermiculite mine from the province of Córdoba (Argentina): a case study. Environ. Earth Sci. 76(18), 1-20 (2017b)

Locati, F., Lescano, L., Murra, J., Marfil, S., Maiza, P., Baldo, E.: Asbestiform amphiboles in a marble quarry: a case study from the province of Córdoba (Argentina), vol. 5. In: IAEG XII Congress, Torino, Italy, pp. 1281-1284 (2014)

Naipauer, M., Vujovich, G.I., Cingolani, C.A., McClelland, W.C.: Detrital zircon analysis from the Neoproterozoic-Cambrian sedimentary cover (Cuyania terrane), Sierra de Pie de Palo, Argentina: evidence of a rift and passive margin system? J. S. Am. Earth Sci. 29(2), 306-326 (2010)

Ramos, V.A, Escayola, M., Mutti, D., Vujovich, G.I. Proterozoic-early paleozoic ophiolites of the Andean basement of southern South America. In: Dilek, Y., Moores, E.M., Elthon, D., Nicolas, A. (eds.) Ophiolitic and Oceanic Crust: New Insights from Field Studies and the Ocean Drilling Program, vol. 349, pp. 331-349. Geological Society of America Special Paper (2000)

Rodríguez, E.J.: Asbestos banned in Argentina. Int. J. Occup. Environ. Health 10(2), 202-208 (2004)

Ross, M., Langer, A.M., Nord, G.L., Nolan, R.P., Lee, R.J., Van Orden, D., Addison, J.: The mineral nature of asbestos. Regul. Toxicol. Pharm. 52(1), 26-30 (2008)

Sfragulla, J., Jerez, D., Bonalumi, A.: Mármoles y otras rocas carbonáticas de Córdoba. In: Zappettini, E.O. (ed.) Recursos Minerales de la República Argentina, vol. 35, pp. 271-295. SEGEMAR, Buenos Aires (1999)

Van Gosen, B.: The geology of asbestos in the United States and its practical applications. Environ. Eng. Geosci. 13(1), 55-68 (2007)

Vignaroli, G., Ballirano, P., Belardi, G., Rossetti, F.: Asbestos fibre identification vs. evaluation of asbestos hazard in ophiolitic rock mélanges, a case study from the Ligurian Alps (Italy). Environ. Earth Sci. 72(9), 3679-3698 (2014)

Whitney, D.L., Evans, B.W.: Abbreviations for names of rock-forming minerals. Am. Miner. 95, 185-187 (2010)

World Health Organization (WHO): Asbestos and other natural mineral fibres. In: International Programme on Chemical Safety, vol. 53. World Health Organization, Geneva. Environmental Health Criteria, $194 \mathrm{pp}$ (1986) 


\section{Author Index}

$\mathbf{A}$

Abe, Ana C.P., 99

Agyemang, Adu, 91

Aldo, 169

Alves, L.E.C., 69

\section{B}

Beauty, Adela, 91

Bonalumi, 169

Briaud, Jean-Louis, 1

Broetto, M.Z., 69

Burova, V., 33

\section{C}

Caldeira, Laura, 75

Cripps, J.C., 143

Czerewko, M.A., 143

\section{D}

da Silva, Paula F., 39

de Lollo, José Augusto, 99, 107

Dippenaar, Matthys A., 63

Doglioni, Angelo, 161

$\mathbf{E}$

Espíndola, Murilo S., 55, 69

Esquivel, Edmundo Rogério, 27

F

Francisco, 169

G

Guerrero, João V.R., 99

\section{H}

Hamel, James V., 121

Hickel, V.F., 69
J

Jeremias, Filipe Telmo, 75

Johnson, W., 153

Jorge, 169

Joyner, Andrew, 91

$\mathbf{K}$

Karfidova, E., 33

$\mathbf{L}$

Lacertosa, Rosa Maria, 161

Lescano, Leticia, 169

Lima, Jacqueline Zanin, 129

Locati, 169

Lorandi, Reinaldo, 99, 107

Luffman, Ingrid, 91

M

Maiza, 169

Marques, Jéssica Pelinsom, 27

Marteli, Alice N., 107

Marfil, Silvina, 169

Mirjafari, Yasin, 47

Mraz, Elena, 21

Müller, Vitor S., 55, 69

$\mathbf{N}$

Nandi, Arpita, 91

Nascimento, Marivaldo S., 55

Noveletto, Vanessa, 55

o

Oliveira, Priscilla H.P., 83

Orense, Rolando P., 47

$\mathbf{P}$

Pan, Kun, 15

Paul, Darren, 7 